\title{
Problematika Status Anak Angkat di Randublatung Blora dalam Perspektif Fatwa MUI
}

\author{
Fathonah K. Daud \\ IAI Al Hikmah Tuban \\ J1. PP. Al Hikmah Binangun Singgahan Tuban, Jawa Timur, Indonesia 62361 \\ fathkasuwi@gmail.com \\ M. Ridlwan Hambali \\ UNU Sunan Giri Bojonegoro \\ Jl. A. Yani no. 10 Bojonegoro, Jawa Timur Indonesia 62115 \\ Ridlwan2020@gmail.com
}

\begin{abstract}
This paper discuss the problem of the status of adopted children in Randublatung sub district, Blora, Central Java from the perspective of the MUI Fatwa. The research method in this writing is a combined study of field research and library research. The data oblained by researchers from the results of interviews, field observations and collecting literature or literature related to the theme of the study and presented in a descriptive qualitative form. The results showed that the MUI Fatwa regarding child adoption has been based on authoritative arguments in Islam. Meanwhile, the care for adopted children at Randublatung Blora has been donw well. However, in the procedure, from the perspective of MUI, the adoptive parents have committed a practices that is contrary to the teachings of Islam, namely registering the name of having occupied the biological father on the birth certificate of the adopted child. As a result, such as the family card and diploma of the child, starting from kindergarten to university level diplomas.
\end{abstract}

Keywords: Adoption of children, Randublatung, the MUI fatwa

\begin{abstract}
Abstrak
Tulisan ini membahas problematika status anak angkat di kecamatan Randublatung Blora Jawa Tengah dalam perspektif Fatwa MUI. Metode penelitian dalam penulisan ini adalah studi gabungan antara studi lapangan (field research) dan literature (library research). Data didapatkan peneliti dari hasil interviu, pengamatan lapangan, dan mengumpulkan literatur-literatur atau pustaka yang terkait dengan tema kajian dan disajikan dalam bentuk descriptive qualitative. Hasil penelitian menunjukkan bahwa Fatwa MUI tentang adopsi anak telah berdasarkan kepada dalil yang otoritatif dalam Islam. Adapun pengasuhan anak angkat di Randublatung Blora telah dilakukan dengan baik. Namun dalam prosedurnya, dalam perspektif MUI, orang tua angkat tersebut telah melakukan praktik yang bertentangan dengan ajaran agama Islam, yaitu mencatatkan namanya telah menduduki ayah kandungnya di Akte kelahiran anak angkat. Akibatnya, menjadikan dampak kepada dokumen penting keluarga yang lainnya, seperti Kartu Keluarga dan ijazah anak tersebut, mulai dari TK hingga ijazah tingkat Perguruan Tinggi.
\end{abstract}

Kata Kunci: Adopsi anak, Randublatung, fatwa MUI

\section{PENDAHULUAN}


Dalam Islam, mengadopsi anak diperbolehkan (mubâh), bahkan dipandang sebagai perbuatan terpuji. Adopsi yaitu mengangkat anak orang lain untuk diperlakukan dan diasuh sebagaimana anak sendiri, namun dilarang memutus hubungan nasab dengan orang tua kandungnya. Demikian juga dalam pandangan hukum adat di masyarakat diperbolehkan, asalkan tidak melanggar beberapa hal yang sudah ditentukan dalam adat tersebut.

Di Indonesia, tata cara dan peraturan mengangkat anak (adopsi) yang sesuai dengan hukum, ditetapkan dalam Undang-Undang Nomor 23 Tahun 2002 tentang Perlindungan Anak (UU Perlindungan Anak) dengan peraturan pelaksana berupa Peraturan Pemerintah Nomor 54 Tahun 2007 tentang Pelaksanaan Pengangkatan Anak (PP Adopsi) dan dijelaskan lebih rinci dalam Peraturan Menteri Sosial No. 110 Tahun 2009 tentang Persyaratan Pengangkatan Anak.

Namun, fakta di lapangan sudah lama menunjukkan bahwa masih banyak praktik adopsi yang tidak sesuai dengan hukum Islam, tidak dicatatkan, dan tidak sesuai prosedur resmi hukum positif maupun prosedur adat setempat. Hal ini dapat membawa implikasi yang buruk bagi kelanjutan anak adopsi tersebut di masa depan, baik dari sisi psikologis dan sosiologisnya. Dalam beberapa penelitian praktik adopsi anak yang berkembang di beberapa masyarakat, telah menunjukkan bahwa praktiknya meliputi berbagai macam kasus. Antaranya, ketidakjelasan kewenangan perkara adopsi di Pengadilan Negeri dan Pengadilan Agama di tingkat kabupaten, pemalsuan dokumen, adanya perbedaan Standart Operational Procedure (SOP) di antar Kabupaten, bahkan tidak sedikit ada yang mengganti Akta kelahiran dengan nama ayah angkatnya. ${ }^{1}$

Dalam persoalan ini, Majelis Ulama Indonesia (MUI) turut meresponnya dan memberikan fatwanya sebagai jawaban atas hukum adopsi dalam Islam dan ke-Indonesiaan, agar dapat memberi pemahaman kepada masyarakat luas. Fatwa ini telah ditetapkan pada tahun $1984 \mathrm{M} / 1404 \mathrm{H}$, sebenarnya lumayan sudah cukup lama. ${ }^{2}$ Tetapi seakan-akan masyarakat belum faham terkait aturan yang berlaku dan hukum adopsi anak, sehingga praktiknya di masyarakat masih ada saja yang tidak mengikuti aturan hukumnya.

Metode penelitian dalam penulisan ini adalah studi gabungan antara studi lapangan (field research) dan literature (library research). Data didapatkan peneliti dari hasil

\footnotetext{
${ }^{1}$ Nina Mariani Noor dan Ro'fah, Praktik Adopsi Anak dan Peran Pekerja Sosial dalam Proses Adopsi Anak di Daerah Istimewa Yogyakarta, Jurnal PKS, vol. 18, no. 2, Agustus 2019, hlm. 95-112

${ }^{2}$ DP MUI, Fatwa MUI no. IX tentang Adopsi (Pengangkatan Anak), ditetapkan di Jakarta pada 4 Jumadil Akhir 1404 H/ 7 Maret 1984 M.
} 
penelitian kasus adopsi anak di kecamatan Randublatung, dan mengumpulkan literaturliteratur atau pustaka yang terkait dengan tema kajian dan disajikan dalam bentuk descriptive qualitative. Metode ini merupakan serangkaian kegiatan lapangan, dengan melakukan survei dan interviu. Disamping itu dengan pengumpulan data kepustakaan, melalui pembacaan terhadap tema-tema yang serupa, diteliti, dicatat dan kemudian diolah dengan menggunakan literature review. Selanjutnya diperdalam kajian teoritisnya dalam penerapannya menurut fatwa MUI dalam tema adopsi anak.

Oleh itu, penelitian ini memberikan fokus kepada praktik dan problematika adopsi anak di kecamatan Randublatung kabupaten Blora Jawa Tengah, dalam tinjauan fatwa MUI. Dimana kasus adopsi di Randublatung tersebut hanyalah satu sample atas fenomena dan praktik adopsi umat Islam di Indonesia. Tujuan pembahasan ini adalah untuk memahami kasus adopsi anak tersebut dalam tinjauan hukum Islam Indonesia.

\section{PEMBAHASAN}

\section{Pengertian Adopsi, Tabanni Dan Anak Angkat}

Dalam pengertian ini ada tiga istilah yang harus didefinisikan, karena diantara istilah-istilah tersebut terdapat perbedaan. Pertama, pengertian adopsi. Istilah adopsi diserap dari kata adoptie (bahasa Belanda), atau adoption (bahasa Inggris), artinya mengangkat anak. Menurut Syaikh Mahmud Saltut, ada dua macam definisi tentang adopsi anak. ${ }^{3}$ Pertama adopsi diartikan pengangkatan seseorang terhadap anak orang lain dan disatukan ke dalam keluarganya. Kemudian ia memperlakukan anak tersebut sama dengan anaknya dalam segi pelayanan dan pemenuhan kebutuhannya, dan bukan diberlakukan sebagai anak nasabnya. Seseorang yang mengangkat anak dan diketahui bahwa anak tersebut anak orang lain, lalu ia menjadikannya, seakan, sebagai anaknya sendiri yang sah, dengan merubah status anak tersebut menjadi anaknya yang sah secara hukum dan antara keduanya dapat saling mewarisi. Definisi yang kedua ini sama dengan pengerian tabanni.

Kedua, menjelaskan istilah tabanni. Secara bahasa, tabanni dari bahasa Arab 'التبنيّ',

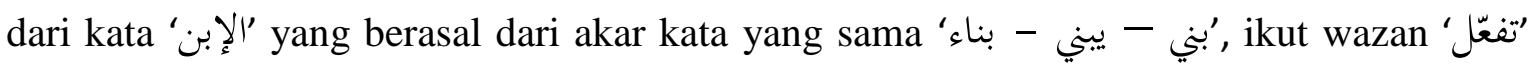

\footnotetext{
${ }^{3}$ Mahmud Syaltut, Al-Fatawa, (Cairo: Dar el-Qalam, t.th), hlm. 321
} 
yang diartikan menurut kamus al-Munjid 'اتّخذهُ إبنا', artinya menjadikannya anak. ${ }^{4}$ Dalam pengertian fuqaha, menjadikan anak orang lain sebagai anak kandungnya. ${ }^{5}$

Ketiga, anak angkat atau anak asuh. Anak angkat dalam pengertian hukum adalah seorang yang bukan keturunan dua orang suami isteri yang diangkat, diasuh, dan diperlakukan sebagai anak keturunannya sendiri. ${ }^{6}$ Dalam KHI pasal 171 huruf h, dijelaskan pengertian anak angkat. Anak angkat adalah anak yang dalam pemeliharaan dan kebutuhan hidupnya sehari-hari, biaya pendidikan dan sebagainya beralih tanggungjawabnya dari orang tua kandung kepada orang tua asuhnya berdasarkan keputusan pengadilan. ${ }^{7}$ Definisi ini seperti pengertian adopsi yang pertama.

Dari ketiga istilah tersebut sepintas ada kemiripan, tetapi sebenarnya ada perbedaan pengertian antara tabanni, adopsi dan mengangkat anak. Tabanni adalah menjadikan anak orang lain dijadikan sebagai anak sendiri dan dinasabkan kepada orang tua asuh, dalam hal ini Islam tidak membenarkan dan tidak mengenal ajaran seperti ini. Sementara adopsi, sebagaimana didefinisikan di atas, apabila anak orang lain itu dijadikan anak sendiri yang sah, maka ini juga dilarang dalam agama Islam, karena ini sama dengan pengertian tabanni. Tetapi apabila tujuan adopsi anak orang lain hanya ingin mengasuhnya dan memperlakukannya sebagaimana anak sendiri dari segi perhatian dan tetap mengekalkan identitas asli anak tersebut, maka hal ini sama dengan mengangkat anak dan diperbolehkan dalam Islam. Orang yang mengangkat anak orang lain untuk dipelihara dan diasuhnya untuk tujuan menolongnya, justeru mendapat pahala di sisi Islam.

\section{Kasus Adopsi Anak di Randublatung Kabupaten Blora \\ Data Informan}

Tabel berikut ini merupakan data informan terkait kasus adopsi anak di Randublatung Blora Jawa Tengah. Mereka ini dipilih berdasarkan pengetahuan mereka pada peristiwa adopsi anak sejak dari awal prosesnya hingga hari ini. Adapun nama informan sengaja dirahasiakan untuk kepentingan penelitian ini, dan hanya disajikan dalam bentuk inisial saja. 50

${ }^{4}$ Al-Yassu'I, Louis Macluf, Al-Munjied fi al-Lughah, (Beirut: Dar al-Masyreiq, 1973) cet. 26, hlm.

5 Tim Kementerian Perwakafan dan Keislaman, al-Mausucah al-Fiqhiyyah al-Kuwaitiyyah, (Kuwait: Dârr al-Salasil, 1427 H) cet. II, Jil. 41

${ }^{6}$ Sudarsono, Kamus Hukum, (Jakarta: PT Rineka Cipta dan PT Bima Andiaksara, 2005), hlm. 32

${ }^{7}$ Instruksi Presiden no. 1 tahun 1991 tentang Kompilasi Hukum Islam. 
Data Informan Kasus Adopsi Anak

\begin{tabular}{|c|l|l|l|l|l|l|}
\hline No & $\begin{array}{l}\text { Nama } \\
\text { Inisial }\end{array}$ & Umur & \multicolumn{1}{|c|}{ Status } & Pendidikan & Pekerjaan & \multicolumn{1}{|c|}{ Alamat } \\
\hline 1. & $\mathrm{Kh}$ & 55 & $\begin{array}{l}\text { Ayah } \\
\text { angkat }\end{array}$ & S1 & PNS & Randublatung Blora \\
\hline 2 & $\mathrm{~N}$ & 49 & Ibu angkat & SMA & $\begin{array}{l}\text { Iburumah } \\
\text { tangga }\end{array}$ & Randublatung Blora \\
\hline 3 & $\mathrm{Kr}$ & 24 & $\begin{array}{l}\text { Anak } \\
\text { angkat }\end{array}$ & $\mathrm{S} 2$ & Pelajar & Randublatung Blora \\
\hline 4 & $\mathrm{Mr}$ & 52 & $\begin{array}{l}\text { Om anak } \\
\text { angkat }\end{array}$ & $\mathrm{S} 3$ & Dosen & Bojonegoro \\
\hline 5 & $\mathrm{M}$ & 27 & $\begin{array}{l}\text { Sepupuh } \\
\text { anak angkat }\end{array}$ & $\mathrm{S} 1$ & Guru MI & $\begin{array}{l}\text { Desa Weni } \\
\text { Randublatung Blora }\end{array}$ \\
\hline 6 & $\mathrm{Mah}$ & 65 & $\begin{array}{l}\text { Bulek ayah } \\
\text { kandung Kr }\end{array}$ & $\begin{array}{l}\text { Pondok } \\
\text { pesantren }\end{array}$ & Bunyai & Bangilan \\
\hline
\end{tabular}

\section{Uraian Kasus Anak Angkat}

Menurut Mr, pada bulan Agustus tahun 1998, orang tua Kr mendapat tugas dari Kemenag Tuban untuk berdakwah di daerah transmigrasi wilayah Pidi Aceh Utara. Waktu berangkat dari Tuban ke Pidi Aceh ini, keluarga Kr terdiri dari ayah, ibu dan 2 saudara yang lain. $\mathrm{Kr}$ adalah anak paling kecil dan lahir pada tahun 1997. Kr dan keluarganya berada di Pidi Aceh sekitar 2 tahun. Sepulang dari Aceh, keluarga Kr tinggal empat orang, karena ayah Kr meninggal dunia di Pidi Aceh. ${ }^{8}$

Ibu $\mathrm{Kr}$ membawa anak-anaknya kembali ke rumah orang tua ayah $\mathrm{Kr}$, yang ketika itu berada di daerah Bangilan Tuban. $\mathrm{Kr}$ dan kedua saudaranya hidup sederhana, karena ibu $\mathrm{Kr}$ tidak mempunyai pekerjaan tetap. Ibu $\mathrm{Kr}$ adalah seorang hafidzah, yang apabila ada undangan pengajian penduduk untuk khataman saja ia akan mendapatkan rezeki. Itupun tidak seberapa, karena hanya pemberian seikhlasnya saja. Sehingga segala kebutuhan $\mathrm{Kr}$ sekeluarga bergantung kepada nenek $\mathrm{Kr}$ di Bangilan tersebut. Meskipun tidak tergolong orang kaya, tapi nenek $\mathrm{Kr}$ mampu mencukupi kebutuhan sandang dan pangan $\mathrm{Kr}$ sekeluarga. ${ }^{9}$

Karena keadaan yang sempit tersebut, pada tahun 2002, Kr diadopsi oleh kerabat dekat ayahnya, yang bernama $\mathrm{Kh}$ dan $\mathrm{N}$. Kh dan $\mathrm{N}$ ini adalah pasangan suami isteri yang tinggal di Randublatung Blora Jawa Tengah. Menurut pengakuan Mr. prosedur pengangkatan anak ini hanya menggunakan tata cara adat dan kekeluargaan, dengan

\footnotetext{
${ }^{8} \mathrm{Mr}$, Wawancara pribadi, Pada hari Sabtu, 8 Januari 2021.

${ }^{9}$ Mah, Wawancara pribadi, Pada hari Senin, 4 Januari 2021.
} 
disaksikan oleh beberapa keluarga dekat, tanpa ada proses di Pengadilan. ${ }^{10}$ Hal ini karena antara keluarga Kh dengan keluarga ibu kandung Kr masih tergolong kerabat dekat. Dari hasil penelusuran peneliti, proses adopsi anak tersebut telah mendapat persetujuan dari ibu kandung $\mathrm{Kr}$ dan izin dari pak Dhe kandung dan nenek kandung Kr. Bahkan peristiwa ini telah disaksikan oleh keluarga besar ayah kandung Kr. Saat itu posisi Kr menjadi anak yatim yang telah ditinggal mati oleh ayah kandungnya.

Menurut M, alasan mengadopsi ini selain untuk membantu biaya hidup dan pendidikan ke depan $\mathrm{Kr}$, juga untuk tujuan sebagai pancingan agar istri $\mathrm{Kh}$ segera mengandung. Tentu ini adalah berdasarkan keyakinan masyarakat lokal saja dan tidak ada dasar hukumnya. ${ }^{11}$ Menurut Kh, waktu itu ia sudah menikah sekitar 5 tahun, tetapi belum mendapat karunia anak. ${ }^{12}$

Dalam pengamatan penulis, dilihat dari seni bangunan dan penghasilannya, keluarga $\mathrm{Kh}$ ini hidup dalam kemapanan dan termasuk kategori kaya. Waktu awal diadopsi, tentu saja Kr tidak memahami jika akhirnya ia harus terpisahkan dengan saudara-saudara kandungnya, karena ia masih terlalu kecil untuk dapat memahami keadaan. Yang ia fahami telah berada dan tinggal bersama dengan keluarga yang dapat mencukupi keperluannya dan pendidikannya. Semua kebutuhannya nyaris tidak ada yang kurang, bahkan terkesan dimanjakan karena ia adalah anak satu-satunya dambaan bagi pasangan Kh dan N. Ketika awal-awal itu, ibu kandung $\mathrm{Kr}$ pun dilarang untuk menjengut atau sekedar mengunjunginya dan itu berlanjut sampai beberapa tahun kemudian. Keadaan inilah yang membuat $\mathrm{Kr}$ cepat melupakan ibu dan kedua saudaranya. Terlebih $\mathrm{Kr}$ sangat disayangi keluarga barunya ini. Wal hasil, dalam akta kelahiran $\mathrm{Kr}$ pun telah berubah menjadi $\mathrm{Kr}$ binti Kh. ${ }^{13}$

Menurut Mr, Kr mendapat pendidikan yang terbaik. Setelah lulus sekolah dasar, $\mathrm{Kr}$ dikirim ke pondok oleh orang tua angkatnya sekaligus sekolah di SMP Al-Fatimah Bojonegoro. Sekolah atau pondok ini termasuk sekolah favorit di Bojonegoro dan terakreditasi A. Saat itu Kr pun tidak pernah teringat lagi keluarga asalnya, atau dapat dikatakan memang betul-betul tidak tahu lagi siapa orang tua dan saudara-saudara kandungnya. Terlebih orang tua angkat dan keluarga dekatnya tidak pernah menceritakan dan bahkan seakan sengaja menutup-nutupi hal tersebut. Sepertinya, yang Kr tahu, bahwa

\footnotetext{
${ }^{10} \mathrm{Mr}$, Wawancara pribadi, Pada hari Sabtu, 8 Januari 2021.

${ }^{11}$ M, Wawancara pribadi, Pada hari Minggu, 10 Januari 2021.

${ }^{12}$ Kh, Wawancara pribadi, Pada hari Sabtu, 9 Januari 2021.

${ }^{13}$ M, Wawancara Pribadi, Pada Hari Minggu, 10 Januari 2021.
} 
dirinya adalah anak dari pasangan $\mathrm{Kh}$ dan $\mathrm{N}$. Hal itu terlihat dari prilaku dan sifat manja $\mathrm{Kr}$ terhadap orang tua angkatnya, yang seakang orang tuanya sendiri. ${ }^{14}$

Seiring berjalannya waktu, setelah lulus dari SMP-SMA Al Fatimah pada tahun 2013, Kr melanjutkan studinya di kampus Unwahas Semarang dan ambil jurusan Farmasi hingga di tingkat Master (S2). Pada saat di Semarang inilah, Kr rupanya baru memahami keadaannya yang sesungguhnya bahwa ianya adalah membesar dan diasuh oleh orang tua angkatnya. Dalam pengakuan $\mathrm{Kr}$, tentu saja ia sedih awalnya ketika baru memahami bahwa ia hanyalah anak angkat dan bukan anak kandung dari orang yang selama ini ia panggil ibu dan ayah. ${ }^{15} \mathrm{Kr}$ tidak pernah mau menceritakan dari siapa sumber berita tersebut. Intinya, selama di Semarang ini ia telah banyak bergaul dengan banyak teman dan secara kebetulan beberapa kali ia bertemu dengan saudara-saudara kandungnya. Mungkin di saat inilah wawasan tentang asal muasal dirinya mulai terkuak, tentunya dari beberapa sumber yang selama ini ia kumpulkan dan pendam. Perlu disampaikan, bahwa domisili keluarga ibu kandung dan saudara-saudara Kr ini berada di Purwodadi, sehingga aksesnya lebih dekat ke Semarang. Meskipun dengan kondisi sedikit galau, $\mathrm{Kr}$ pun secara sembunyi-sembunyi pada akhirnya dapat bertemu dengan ibu kandungnya, A, di Purwodadi.

Ketika peneliti menanyakan perihal kedudukan $\mathrm{Kr}$ saat ini, apakah ia ingin kembali kepada orang tua asalnya. Tentu saja ada perasaan galau, karena bagaimana pun ia sudah lama terpisah dari keluarganya. Di sisi lain, statusnya selama ini telah disembunyikan oleh orang tua angkatnya. Namun, kini ia sudah membesar dan dewasa, tentunya sudah dapat menempatkan dirinya dimana yang terbaik. Tetapi jika ia akan kembali kepada ibu kandungnyam tentu ia pun merasa tidak etis dengan orang tua angkatnya. Bagaimana pun mereka telah berjasa membesarkan dan memberi pendidikan yang terbaik kepadanya.

Kini, telah nyata semuanya, sedangkan akta kelahiran yang tertulis adalah Kr binti Kh. Bahkan di semua ijazah pendidikan Kr tertulis, bahwa Kr adalah anak dari Kh. Inilah yang membuat bingung $\mathrm{Kr}$, karena sejatinya ia sudah memahami bahwa dirinya lahir dari keluarga pasangan Im dan A, bukan dari pasangan Kh dan N. Namun, lambat laun, kabar tentang $\mathrm{Kr}$ sudah menemui orang tua kandungnya pada akhirnya terdengar oleh keluarga Kh. Menurut M, Kh tentu saja tidak mau kalah dan melepaskan anak angkatnya begitu saja, karena sudah terlanjur menyayanginya dan kemungkinan akan berat jika harus merubah

\footnotetext{
${ }^{14}$ Mr, Wawancara Pribadi, Pada Hari Sabtu, 9 Januari 2021.

${ }^{15} \mathrm{Kr}$, Wawancara Pribadi, Pada hari Senin, 11 Januari 2021.
} 
seluruh akta atau dokumen yang tertulis bahwa $\mathrm{Kr}$ binti $\mathrm{Kh} .{ }^{16}$ Inilah yang membuat $\mathrm{Kr}$ dan seluruh keluarga dari orang tua kandungnya menyesalkan, bahkan ada yang kurang terima terkait hal itu. Bagaimanapun keluarga mereka semua memahami hukum agama.

Ringkasan Temuan Penelitian

\begin{tabular}{|c|l|l|l|}
\hline No & \multicolumn{1}{|c|}{ Hasil Temuan } & Pelaku & Keterangan \\
\hline 1 & $\begin{array}{l}\text { Tujuan adopsi selain untuk membantu biaya } \\
\text { hidup dan pendidikan ke depan anak angkat, } \\
\text { juga untuk tujuan sebagai pancingan ibu } \\
\text { angkat agar segera mengandung. }\end{array}$ & $\begin{array}{l}\text { Orang tua } \\
\text { angkat }\end{array}$ & Baik \\
\hline 2 & $\begin{array}{l}\text { Proses adopsi anak hanya dilakukan di depan } \\
\text { kerabat dekat, tanpa melalui prosedur di } \\
\text { Pengadilan. }\end{array}$ & $\begin{array}{l}\text { Orang tua } \\
\text { angkat }\end{array}$ & Pelanggaran \\
\hline 3 & $\begin{array}{l}\text { Status orang tua kadung disembunyikan } \\
4\end{array}$ & $\begin{array}{l}\text { Pencatatan akte dan dokumen penting anak } \\
\text { angkat binti ayah angkat }\end{array}$ & $\begin{array}{l}\text { Orang tua } \\
\text { angkat } \\
\text { angkat }\end{array}$ \\
\hline
\end{tabular}

\section{Fatwa Majlis Ulama Indonesia tentang Adopsi Anak}

Majlis Ulama Indonesia atau disingkat MUI merupakan badan atau lembaga keagaamaan independen yang mewadahi para ulama dan cendekia Muslim untuk membimbing, membina dan mengayomi umat Islam di Indonesia. MUI dapat juga disebut sebagai lembaga fatwa Indonesia. Di sini eksistensi MUI bagi masyarakat Indonesia sangat signifikan, terutama dalam merespon permasalahan umat Islam yang selalu dinamis. ${ }^{17}$

Sejak berdiri pada tanggal 26 Juli 1975, MUI telah berupaya mengambil peran sebagai problem solver dalam masalah keluarga dengan cara mengeluarkan fatwa yang terkait masalah keluarga. ${ }^{18}$ Meskipun fatwa MUI ini tidak mengikat karena tidak mengandung kekuatan hukum, tetapi fatwa MUI telah memberikan pengaruh terhadap pemahaman agama dan kehidupan masyarakat di Indonesia. MUI bagaimana pun dipandang oleh sebagian masyarakat Muslim dan pemerintah sebagai corong agama, terlebih MUI tidak berafiliasi ke partai politik atau pun ke organisasi kemasyarakatan dan keagamaan tertentu. Maka fatwa MUI diterima oleh masyarakat muslim Indonesia dengan baik, bahkan ada yang menganggap perlu direalisasikan secara taken for granted. Sifat fatwa yang bersifat

${ }^{16}$ M, Wawancara pribadi, Pada hari Minggu, 10 Januari 2021.

${ }^{17}$ K. Daud, Fathonah \& Aden Rosadi, Perlindungan Hak-Hak Perempuan dalam Fatwa MUI Bidang Munakahat Perspektif Maslahah, Al-Ahwal Al-Syakhsiyyah, vol. 2, no. 1 (2021), hlm. 20

${ }^{18}$ DP MUI, Fatwa MUI no. XX tentang Nikah Wisata, ditetapkan di Jakarta pada 13-16 Sya'ban 1431

/ 25-28 Juli 2010 M, nomor 02/MUNAS-VIII/MUI/2010 
kasuistik, tidak memiliki daya ikat, dan dinamis telah mendorong adanya rekayasa sosial dalam masyarakat muslim Indonesia khususnya di bidang hukum keluarga.

Pada tahun 1994, melalui Rapat Kerja Nasional Majelis Ulama Indonesia yang berlangsung pada bulan Jumadil Akhir 1404 H./Maret 1984 menetapkan Fatwa tentang Adopsi (Pengangkatan Anak), sebagai berikut: ${ }^{19}$

1. Islam mengakui keturunan (nasab) yang sah, ialah anak yang lahir dari perkawinan (pernikahan).

2. Mengangkat anak dengan pengertian anak tersebut putus hubungan nasabnya dengan ayah dan ibu kandungnya adalah bertentangan dengan syari'ah Islam.

3. Adapun adopsi anak dengan tidak mengubah status nasab dan Agamanya, dilakukan atas rasa tanggung jawab sosial untuk memelihara, mengasuh dan mendidik mereka dengan penuh kasih sayang, seperti anak sendiri adalah perbuatan yang terpuji dan termasuk amal saleh yang dianjurkan oleh agama Islam.

4. Pengangkatan anak Indonesia oleh Warga Negara Asing selain bertentangan dengan UUD 1945 Pasal 34, juga merendahkan martabat bangsa.

Dalil dan Dasar Hukum tentang Adopsi

Adapun fatwa MUI tentang adopsi anak berdasarkan beberapa dalil berikut ini:

1. Al-Quran Surat al-Ahzab [33]: 4:

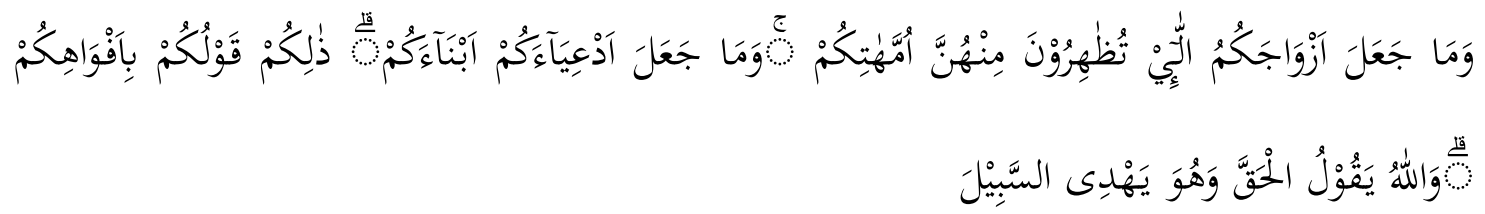

Artinya: "Dan, dia tidak menjadikan anak-anak angkatmu sebagai anak kandungmu (sendiri); yang demikian itu hanyalah perkataanmu dimulutmu saja. Dan Allah mengatakan yang sebenarnya dan Dia menunjukkan jalan yang benar."

2. Al-Quran Surat al-Ahzab [33]: 5:

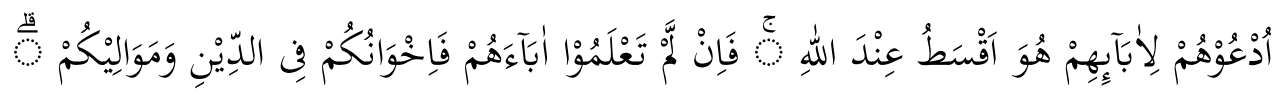

"Panggilah mereka (anak angkat) itu dengan memakai nama bapak-bapak mereka, itulah yang paling adil dihadapan Allah.Jika kamu tidak mengetahui bapak-bapak mereka, maka (panggillah mereka sebagai) saudaramu seagama dan hamba sahaya yang dimerdekakan."

${ }^{19}$ DP MUI, Himpuran Fatwa MUI (Bidang Sosial dan Budaya), melalui Rapat Kerja Nasional Majelis Ulama Indonesia tahun 1984 yang berlangsung pada bulan Jumadil Akhir 1404 H./Maret 1984 menetapkan Fatwa tentang Adopsi (Pengangkatan Anak), hlm. 305-308 
3. Al-Quran Surat al-Ahzab [33]: 40:

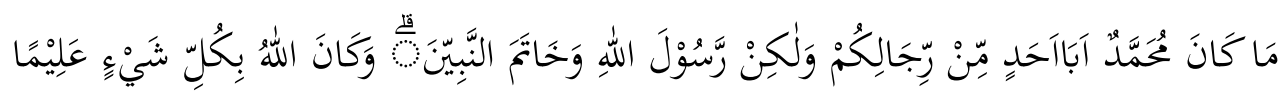

"Muhammad itu sekali-kali bukanlah bapak dari seorang lakilaki diantara, tetapi ia adalah Rasulullah dan penutup nabi-nabi.Dan Allah Maha Mengetahui Segala sesuatu.”

4. Sabda Nabi Muhammad SAW:

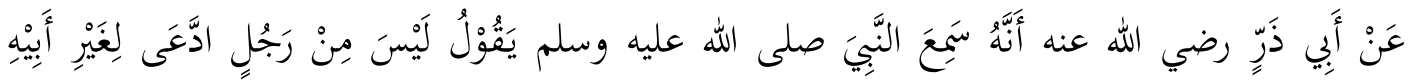

$$
\begin{aligned}
& \text { وَهُوَيَعْلَمُهُ إلاَّ كَفَرَ (رواه الشيخان) }
\end{aligned}
$$

"Dan Abu Zar Ra. Sesungguhnya ia dengar Rasul bersabda: "Tidak seorangpun mengakui (membangsakan diri) kepada bukan ayah yang sebenarnya, sedang ia tahu bahwa itu bukan ayahnya, melainkan ia telah kufur" (HR Bukhari dan Muslim)."

5. Sabda Nabi Muhammad SAW:

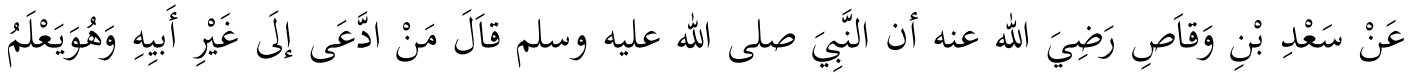

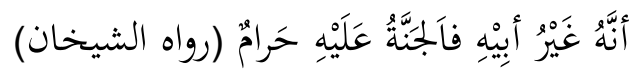

Artinya: "Dari Sa'ad bin Abi Waqqas Ra. Bahwa Rasulullah SAW bersabda "Barang siapa yang mengakui (membangsakan diri) kepadabukan ayahnya padahal ia tahu bahwa bukan ayah kandungnya, haram baginya surga. (HR Bukhari dan Muslim).

6. Hadits Nabi Muhammad SAW:

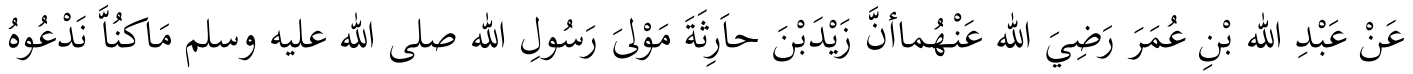

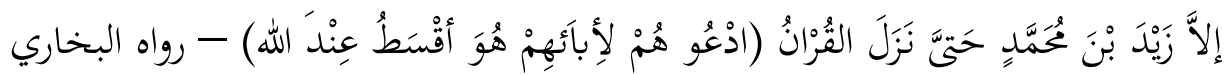

"Dari Abdullah bin Umar bin Khatthab Ra. Sesungguhnya ia berkata: "Kami tidak memanggil Zaid bin Haritsah melainkan (kami panggil) Zaid bin Muhammad, sehingga turun ayat al-Qur'an: Panggilah mereka dengan nama ayah (kandung mereka), itulah yang lebih adil di siai Allah”. (HR Bukhari).

7. Muhammad "Ali As-Sabuni dalam kitabnya "Tafsir Ayat al-Ahkam" halaman 263, jilid 2 menjelaskan sebagai berikut:

"Seperti halnya Islam telah membatalkan Zihar (suami menyerupakan istrinya dengan ibunya), demikian pula halnya dengan tabanni (mengangkat anak) Syariat 
Islam telah mengharamkan keduanya, karena tabanni itu menisbahkan seorang anak kepada orang yang bukan ayahnya, dan itu termasuk dosa besar yang menyebabkan pelakunya mendapat murka dan kutukan Allah. Sesungguhnya Bukhari dan Muslim telah meriwayatkan hadis dari Sa'd bin Abi Waqqas Ra. bahwa Rasulullah saw bersabda: "Barang siapa yang mengakui (membanggakan) diri kepada yang bukan ayahnya, maka wajiblah ia mendapat kutukan dari Allah, para Malaikat dan manusia, serta Allah tidak menerima tasarruf dan kesaksiannya."

8. Pendapat Mahmud Syaltut, ulama' asal Mesir, dalam bukunya al-Fatawa, halaman 292 menulis:

Untuk memahami hukum Islam dalam permasalahan "tabanni" perlu diketahui bahwa "tabanni" itu ada dua macam. Salah satunya seseorang mengangkat anak orang lain untuk diperlakukan seperti anak kandung sendiri, dalam rangka memberi kasih sayang, nafkah, pendidikan dan keperluan lainnya, dan secara hukum anak itu bukan anaknya. "Tabanni" model seperti ini adalah perbuatan yang pantas dilakukan oleh mereka yang luas rezekinya, namun ia tidak dikaruniai anak. Sangat baik apabila mengangkat anak orang lain yang memang kurang mampu secara material, kurang mendapatkan rasa kasih sayang ibu-bapak (karena yatim piatu), atau untuk mendidik dan memberikan kesempatan belajar kepadanya. Karena orang tua kandung anak yang bersangkutan tidak mampu (fakir miskin). Tidak diragukan lagi bahwa usaha semacam ini merupakan perbuatan yang terpuji dan dianjurkan oleh agama serta diberi pahala. Bagi ayah angkat, boleh mewasiatkan sebagian dari harta peninggalannya untuk anak angkatnya, sebagai persiapan masa depannya, agar ia merasakan ketenangan hidup.

\section{Analisis Fatwa MUI tentang Adopsi (Pengangkatan Anak) dalam Perspektif Hukum} Islam

Dari segi pengertian adopsi anak yang diberikan oleh MUI telah sesuai dengan pengertian adopsi yang telah ditetapkan oleh mayoritas ulama. ${ }^{20}$ Demikian juga dasar argumentasi Fatwa MUI telah bersumber dari dasar hukum yang otoritatif. MUI telah mengharamkan cara dan bentuk adopsi yang menyerupai adat Jahiliyyah. Dengan artian anak tersebut menjadi putus jalur keturunan (nasab)nya dengan orang tua kandungnya, karena hal tersebut telah menyerupai tabanni di era Jahiliyyah. Sedang adat tabanni di era Jahiliyyah tersebut telah direformasi oleh syari’ah Islam.

Hal itu sebagaimana telah disabdakan oleh Rasulullah saw: hlm. 241

${ }^{20}$ K. Daud, Fathonah, Tafsir Ayat-Ayat Hukum Keluarga 1, (Banten: Desanta Muliavisitama, 2020), 


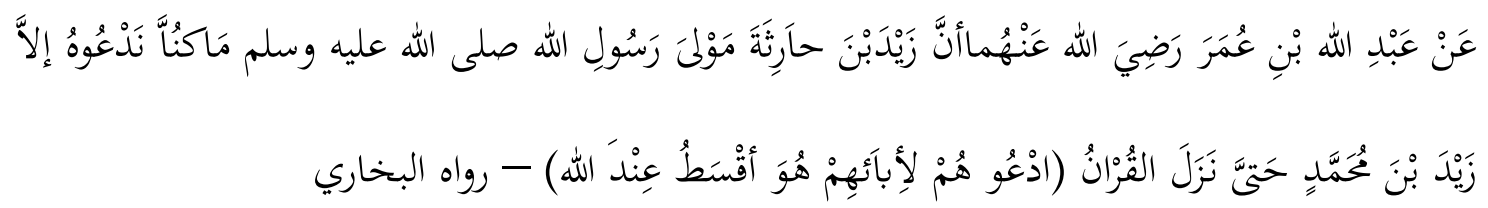

"Dari Abdullah bin Umar bin Khatthab Ra. Sesungguhnya ia berkata: "Kami tidak memanggil Zaid bin Haritsah melainkan (kami panggil) Zaid bin Muhammad, sehingga turun ayat al-Qur'an: Panggilah mereka dengan nama ayah (kandung mereka), itulah yang lebih adil di siai Allah”. (HR Bukhari).

Setelah ayat al-Aḥzâb [33]: 4-5 turun, Islam tidak berarti menghapus tradisi adopsi seluruhnya, tetapi menghapus kebohongannya saja dan memperbaiki hak nasab anak maupun hak-hak orang tua kandung anak. Islam menegaskan bahwa anak angkat tetaplah orang lain. Sehingga anak yang dilahirkan dari keluarga yang kurang berkecukupan secara ekonomi atau terlahir dengan tidak diketahui nasabnya atau anak-anak yang terlantar, maka mereka masih bisa dibesarkan oleh keluarga asuh tetapi anak tersebut harus tetap mempertahankan identitasnya.

Dengan demikian adopsi anak tetap diperbolehkan oleh Islam, tetapi adopsi anak dalam Islam sungguh berbeda dengan adopsi anak pada era Jahiliyyah. Yakni, status anak angkat dalam Islam berbeda dengan anak kandung. Apabila seseorang melakukan adopsi dengan cara-cara seperti Jahiliyyah, maka hukumnya haram. Orang-orang Muslim percaya bahwa Muhammad saw, seperti nabi-nabi sebelumnya yang lain, dikirim oleh Tuhan untuk mengingatkan manusia akan tanggungjawab moral mereka dan mereformasi perilaku-perilaku yang bertentangan dengan Islam. Hukum Islam telah menetapkan bahwa mengangkat anak adalah perbuatan yang mulia, tetapi hubungan hukum antara anak angkat dan orang tua angkat adalah hubungan anak asuh dengan orang tua asuh dan sama sekali tidak menimbulkan nasab. Akibat yuridis dari adopsi ini dalam hukum Islam hanyalah tercipta hubungan kasih sayang dan hubungan tanggungjawab sebagai sesama manusia. 
Dengan Allah swt membatalkan hukum tabanni, berarti hukum yang berkaitan dengannya juga terhapus, yaitu: ${ }^{21}$

1. Menasabkan kepada ayah angkat.

Berdasarkan hadits berikut:

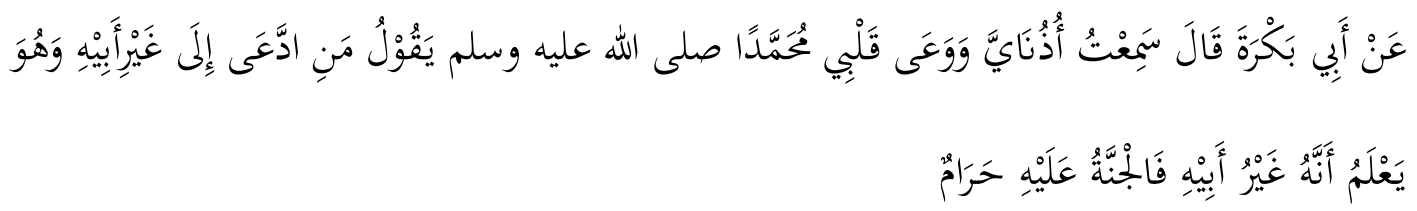

Artinya: Dari Abi Bakrah telah berkata: kedua telingaku mendengar dan hatiku menghafal Nabi Muhammad saw bersabda:"Barang siapa yang menasabkan dirinya kepada lelaki lain selain bapaknya, maka syurga diharamkan bagi dia.(HR. Ibn Majah). ${ }^{22}$

2. Pewarisan antara anak angkat dengan orang tua angkat.

3. Pengharaman menikahi bekas isteri anak angkat pada zaman Jahiliyyah, sebagaimana haramnya menikahi isteri dari anak kandung. Dengan dihapuskannya tabanni, Allah membolehkan menikahi mantan isteri anak angkat setelah bercerai dengannya dan habis masa ${ }^{c}$ iddah-nya. ${ }^{23}$ Hal itu dicontohkan oleh Rasulullah, melalui perintah Allah swt, menikahi Zainab bint Jahsy ibn Riab (bekas isteri Zayd bin Haritsah) pada tahun 5 Hijriyah. Sungguh pun pernikahan jenis ini sangat aib di zaman Jahiliyya, hal ini sebagai penguat bahwa anak angkat adalah bukan mahram, sekaligus sebagai bentuk pemangkas adat Jahiliyyah. ${ }^{24}$

4. Perwalian. Maka ayah angkat tidak bisa menjadi wali pada anak angkat.

5. (e).Pembatalan tabanni tidak berarti menghilangkan nilai amal sosial lainnya, Islam masih membolehkan mengangkat anak dengan tetap mengekalkan identitasnya, tetap menjaga silaturrahim dengan orang tuanya, bahkan mereka yang melakukan mengangkat anak dan meringankan beban orang lain diberi pahala. ${ }^{25}$

Berdasarkan keterangan kasus problem status anak angkat di Randublatung Blora tersebut, dimana ayah angkat telah mencatatkan status anak angkatnya dengan mencantumkan namanya menduduki ayah kandung dari anak angkatnya. Seperti Kr binti

${ }^{21}$ K. Daud, Fathonah, Tafsir Ayat-Ayat Hukum Keluarga 1, ...., hlm. 243-244

${ }^{22}$ Al-Quzwainy, Muhammad bin Yazid Abû Abdillah, Sunan Ibn Majah, (Beirut: Dar al-Fikr, t.th), juz 8, Hadits no. 2708, hlm. 147

${ }^{23}$ Al-Mubarakfuri, Safiyurrahman, Sirah Nabi, (Jakarta: Mizan, 2012), cet.1, hlm. 329

${ }^{24}$ Q.S. Al-Ahzab [33]: 37

${ }^{25}$ Q.S. Al-Nisa' [4]: 36 
$\mathrm{Kh}$, padahal $\mathrm{Kr}$ adalah anak kandung dari orang lain (yaitu Im dan A), sebagaimana yang sudah dijelaskan dalam uraian kasus anak angkat di atas. Keadaan ini telah menjadi persoalan bagi keluarga besar anak angkat, karena hal itu semestinya tidak mungkin dilakukan oleh ayah angkat yang dipandang faham agama. Sedangkan ayah angkat sepertinya masih kekeh mempertahankan apa yang telah dilakukannya, dengan belum ada usaha untuk mengkoreksi ulang apa yang telah dicatatkan baik dalam akte kelahiran anak angkat, Kartu Keluarga (KK) dan dokumen lainnya. Akibatnya memberi dampak kepada pencatatan dokumen yang lain, seperti ijazah anak angkat, mulai dari TK hingga di Perguruan Tinggi. Keadaan ini akibatnya telah terjadi tarik menarik antara kedua belah pihak keluarga tersebut. Meski tidak ditunjukkan dengan adanya konflik keluarga.

Untuk menjawab persoalan ini ada qaidah fiqhiyyah yang berbunyi:

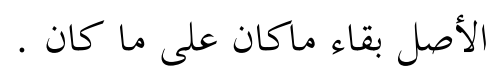

Kaidah ini sangat popular, yang artinya hukum asal adalah ketetapan yang telah dimiliki sebelumnya. ${ }^{26}$ Menurut kaidah di atas, walaupun telah terjadi dramatisir untuk menjadikan anak angkat seperti anak sendiri dengan mencatat nama anak angkat dan dibin(ti)-kan kepada orang tua angkat di beberapa dokumen tertulis, maka hukum anak tetap kembali ke pokok asal adalah tetapnya status anak dari orang tua kandungnya. Hal ini juga sebaimana ketentuan dalam Q.S Al-Aḥzâb [33]: 4-5. Bahwa apa yang telah dipraktikkan oleh orang tua angkat adalah seperti adopsi di zaman Jahiliyyah, yang disebut tabanni. Berdasarkan ayat di atas, Islam telah menghapus adat tabanni pada era Pra-Islam, sehingga Islam sudah tidak mengenal tabanni ${ }^{27}$ Jadi hukum anak angkat tetap sesuai asalnya, anak dari orang tua kandungnya.

Kaidah ini menegaskan bahwa suatu perkara yang telah berada pada satu kondisi tertentu di masa sebelumnya, akan tetap seperti kondisi semula selama tidak ada dalil yang menunjukkan terhadap hukum lain. Alasan utama mengapa hukum yang pertama yang harus dijadikan pijakan, karena dasar segala sesuatu adalah tidak berubah dari kondisi semula. Sedang kondisi baru adalah sesuatu yang bersifat spekulatif.

Oleh itu diharapkan ada pihak-pihak yang dapat menyampaikan kepada ayah angkat tersebut agar segera mengoreksi akte kelahiran anak angkatnya, termasuk dokumen-

\footnotetext{
${ }^{26}$ Darmawan, Kaidah-Kaidah Fiqhiyyah, (Surabaya: Revka Prima Media, 2020), cet. 1, hlm. 17

${ }^{27}$ Al-Zuhaily, Wahbah, Fiqh al-Islam wa Adillatuh, (Damascus: Dar el-Fikr, 2008), Vol. 9, hlm.
} 638 
dokumen keluarga yang lainnya. Sehingga dapat terlepas dari hukuman yang ditegaskan oleh Rasulullah, sebagaimana dalam hadits berikut ini:

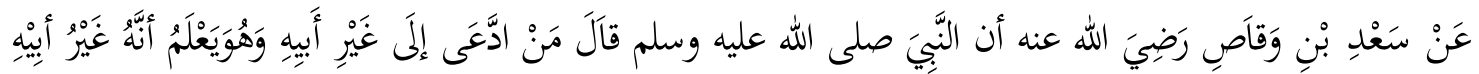

$$
\begin{aligned}
& \text { فاَلَحَنَّةُ عَلَيْهِه حَرامُ (رواه الشيخحان) }
\end{aligned}
$$

"Dari Sa'ad bin Abi Waqqas Ra. Bahwa Rasulullah SAW bersabda "Barang siapa yang mengakui (membangsakan diri) kepada bukan ayahnya padahal ia tahu bahwa dia bukan ayah kandungnya, haram baginya surga. (HR Bukhari dan Muslim).

\section{Analisis Problem Status Anak Angkat di Randublatung Kabupaten Blora dalam Perspektif} Fatwa MUI

Menurut Fatwa MUI, bahwa adopsi anak dengan tidak merubah status, nasab dan agamanya, ia lakukan atas rasa solidaritas sosial untuk mengasuh, memelihara dan mendidik mereka dengan penuh kasih sayang, seperti anak sendiri adalah perbuatan yang terpuji dan termasuk amal saleh yang dianjurkan oleh Islam. ${ }^{28}$ Menurut Mahmud Syaltut, perbuatan seperti ini adalah perbuatan yang patut dilakukan oleh orang-orang yang luas rezekinya, namun ia tidak dikaruniai anak. Sungguh terpuji jika mengadopsi anak dari orang lain yang dipandang kurang mampu untuk memberikan fasilitas yang cukup kepada anak-anaknya, termasuk pada anak-anak yang tiada mendapat rasa kasih sayang dari ibu-bapaknya (karena yatim piatu), atau untuk membantu biaya pendidikan dan memberikan kesempatan belajar kepadanya. Karena orang tua kandung anak tersebut tidak mampu atau tiada. ${ }^{29}$

Berdasarkan paparan kasus atas problem status anak angkat di desa Randublatung Blora Jawa Tengah, apabila ditinjau dari perspektif Fatwa MUI, menunjukkan bahwa perbuatan mengangkat (adopsi) anak tersebut telah bertentangan dengan syariah Islam. Meskipun tujuan adopsi anak tersebut adalah baik dan pengasuhan anak tersebut sungguh sangat baik. Semua kebutuhan dan kasih sayang orang tua angkat kepada anak angkat telah diberikan dengan sangat baik, sebagaimana anak sendiri. Tetapi, karena pihak orang tua angkat tersebut (Kh dan $\mathrm{N}$ ) telah (dengan sengaja) mengganti akta kelahiran anak angkat (seakan) menjadi anak kandung dari ayah angkat tersebut. Hal ini berdasarkan akta kelahiran anak angkat dan bahkan telah berdampak kepada dokumen-dokumen lainnya, seperti tertera di beberapa ijazah pendidikan anak angkat tersebut,

${ }^{28}$ DP MUI, Himpuran Fatwa MUI (Bidang Sosial dan Budaya), melalui Rapat Kerja Nasional Majelis Ulama Indonesia tahun 1984 yang berlangsung pada bulan Jumadil Akhir 1404 H./Maret 1984 menetapkan Fatwa tentang Adopsi (Pengangkatan Anak), hlm. 305-308

${ }^{29}$ Mahmud Syaltut, Al-Fatawa, (Cairo: Dar al-Qalam, t.th), 321 
mulai dari ijazah sekolah Taman Kanak-Kanak (TK) hingga Ijazah di tingkat Perguruan Tingginya. Terlebih orang tua tersebut sengaja menyembunyikan jalur nasab (silsilah) orang tua kandung anak angkat tersebut. Dengan kata lain, nasab anak tersebut sengaja diputus hubungan keturunannya dengan ayah atau ibu kandungnya. Hal ini sungguh bertentangan dengan syari'ah Islam. ${ }^{30}$

Dasar hukum tersebut telah dijelaskan dalam al-Qur'an dan Hadits Nabi saw. Adapun dalil dari Al-Qur'an sebagai berikut:

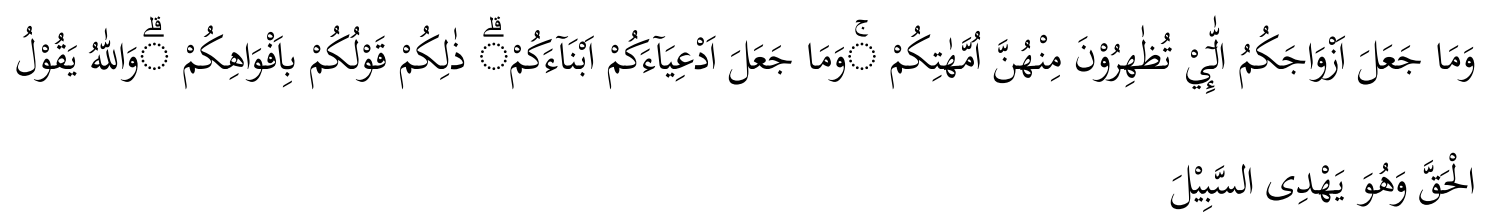

"Dan, dia tidak menjadikan anak-anak angkatmu sebagai anak kandungmu (sendiri); yang demikian itu hanyalah perkataanmu dimulutmu saja. Dan Allah mengatakan yang sebenarnya dan Dia menunjukkan jalan yang benar." 31

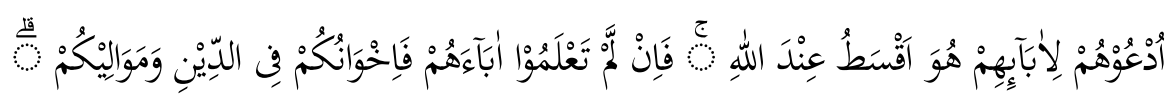

"Panggilan mereka (anak angkat) itu dengan memakai nama bapak-bapak mereka, itulah yang paling adil dihadapan Allah.Jika kamu tidak mengetahui bapak-bapak mereka, maka (panggilah mereka sebagai) saudaramu seagama dan mulamula (hamba sahaya yang di merdekakan). "’32

Sementara dasar dalil dari Hadits sebagaimana sabda Nabi Muhammad SAW:

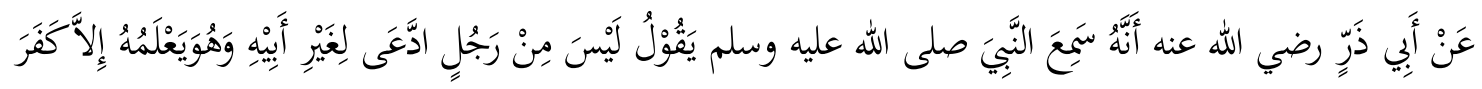

$$
\begin{aligned}
& \text { (رواه الشيخان) }
\end{aligned}
$$

"Dan Abu Zar Ra. Sesungguhnya ia dengar Rasul bersabda: "Tidak seorangpun mengakui (membangsakan diri) kepada bukan ayah yang sebenarnya, sedang ia tahu bahwa itu bukan ayahnya, melainkan ia telah kufur" (HR Bukhari dan Muslim)."

${ }^{30}$ Abu Yazid Adnan dan Ahmad Muzakki, "Urgensi Nasab dalam Islam dan Silsilah Habaib diIndonesia,”Asy Syariah: Jurnal Hukum Islam, Vol. 7, no. 2, 2021, hlm. 139-140

${ }^{31}$ Q.S al-Ahzab [33]: 4

${ }^{32}$ Q.S al-Ahzab [33]: 5 


\section{KESIMPULAN}

Adopsi anak sungguh ada banyak kebaikan sosial di sana. Ia menjadi perhatian dalam Islam, sehingga menjadi pembahasan dalam al-Qur'an. Dalam penelitian ini telah menunjukkan bahwa Fatwa MUI tentang adopsi anak telah berdasarkan kepada dalil yang otoritatif dalam Islam. Adapun kasus problematika status anak angkat di Randublatung kabupaten Blora Jawa Tengah dalam perspektif MUI telah menunjukkan penyelewengan dan bertentangan dengan syariah Islam. Hal itu karena praktik adopsi anak yang dilakukan sebagaimana tabanni, yang telah direformasi oleh Islam.

Oleh karena itu, agar tetap terjalin kekeluargaan yang baik dan silaturahimnya tidak terputus disarankan kepada ayah angkat untuk segera memberi pengertian kepada anak angkatnya dengan klarifikasi bahwa ia adalah anak angkatnya. Sembari diberi penjelasan siapa nama ayah kandung yang sebenarnya, karena inilah ajaran Islam. Selain itu, agar segera mengkoreksi apa yang telah tercatat dalam dokumen-dokumen penting keluarga. Dengan demikian tidak ada kesalahfahaman dan kebohongan di antara orang tua angkat dengan anak angkat serta masyarakat luas. Hal ini dilakukan agar semua jelas hukumnya, yang berdampak kepada hukum perwalian dan kewarisan dalam sudut pandang agama Islam.

Hikmah dari kasus adopsi anak adalah agar anak-anak tetap harus mendapat perhatian kesejahteraannya dalam Islam, karena di pundaknyalah masa depan bangsa dan agama. Oleh itu, Islam sangat menganjurkan untuk menjaga dan mendidik anak-anak secara baik dan sejahtera. Anak-anak adalah amanat Tuhan, yang merupakan ladang pahala dan ruang ujian bagi kedua orang tuanya. Bagi orang tua yang sudah berusaha gigih untuk mengurus anak-anaknya ada kebaikan di sisi Allah swt. Demikian juga, bagi yang ingin mengadopsi anak atas motif dan tujuan yang baik merupakan perbuatan yang terpuji, dan mereka akan diganjar oleh Allah swt. Wallâhu a $a^{c} l a m u$. 


\section{DAFTAR PUSTAKA}

Abu Yazid Adnan dan Ahmad Muzakki, "Urgensi Nasab dalam Islam dan Silsilah Habaib diIndonesia,"Asy Syariah: Jurnal Hukum Islam, Vol. 7, no. 2 (2021)

A. Djazuli, Kaidah-Kaidah Fikih: Kaidah-Kaidah Hukum Islam dalam Menyelesaikan Masalah-Masalah yang Praktis, (selanjutnya disebut Kaidah), Jakarta: Kencana, Cet. ke-1, 2006.

Abnan Pancasilawati, Urgensi Kaidaj Fiqih dan Aplikasinya terhadap Masalah-Masalah Sosial, Fenomena, Vol. IV, no. 2. (2012).

Al-Quzwainy, Muhammad bin Yazid Abû Abdillah, Sunan Ibn Majah, Beirut: Dar al-Fikr, juz 8, Hadits no. 2708, (t.th).

Al-Mubarakfuri, Safiyurrahman, Sirah Nabi, Jakarta: Mizan, cet.1. 2012

Al-Yassu'I, Louis Macluf, Al-Munjid fi al-Lughah, Beirut: Dar al-Masyriq, cet. 26. 1973.

Al-Zuhaily, Muhammad Musthafa, Al-Qawâed al-Fiqhiyyah wa Tațiqatuha fi al-Madzâhib al-Arbacah, Damaskus: Dâr el-Fikr, 2006.

Al-Zuhaily, Wahbah, Fiqh al-Islam wa Adillatuh, Damascus: Dar al-Fikr, Vol. 9, 2008.

Aziz Dahlan, Ensiklopedi Hukum Islam, Jakarta: Ikhtiar Baru Van Hoeve, Jilid III, 2003.

Beni Ahmad Saebani, Filsafat Hukum Islam, Bandung: Pustaka Setia, Cet. ke-1, 2008.

Darmawan, Kaidah-Kaidah Fiqhiyyah, Surabaya: Revka Prima Media, cet. 1, 2020.

Dewan Pimpinan MUI Sumut, Profil Majelis Ulama Indonesia Pusat dan Sumatera Utara, Medan: t.p., 2006.

Dewan Pimpinan MUI Medan, Dokumentasi MUI, Rangkuman Hasil Keputusan MUSDA V Majelis Ulama Indonesia Kota Medan, Medan: t.p., 2001.

Dewan Redaksi, Ensiklopedi Islam, Jakarta: PT. Ichtiar Baru van Hoeve), Jild. 3, 2002.

DP MUI, Fatwa MUI no. IX tentang Adopsi (Pengangkatan Anak), ditetapkan di Jakarta pada 4 Jumadil Akhir 1404 H/ 7 Maret 1984 M.

DP MUI, Fatwa MUI no. XX tentang Nikah Wisata, ditetapkan di Jakarta pada 13-16 Sya'ban 1431 H/ 25-28 Juli 2010 M, nomor 02/MUNAS-VIII/MUI/2010

DP MUI, Himpuran Fatwa MUI (Bidang Sosial dan Budaya), melalui Rapat Kerja Nasional Majelis Ulama Indonesia tahun 1984 yang berlangsung pada bulan Jumadil Akhir 1404 H./Maret 1984 menetapkan Fatwa tentang Adopsi (Pengangkatan Anak).

K. Daud, Fathonah, Tafsir Ayat-Ayat Hukum Keluarga 1, Banten: Desanta Muliavisitama, 2020.

K. Daud, Fathonah, Perlindungan Hak-Hak Perempuan dalam Fatwa MUI Bidang Munakahat Perspektif MAslahah, Al-Ahwal Al-Syakhsiyyah, vol. 2, no. 1, (2021).

Heri Firmansyah, Qawaid Fiqhiyyah Dalam Fatwa Majelis Ulama Indonesia, Al-Qadhâ: Vol. 6, No. 2, Juli, (2019).

Instruksi Presiden no. 1 tahun 1991 tentang Kompilasi Hukum Islam.

Mahmud Syaltut, Al-Fatawa, Cairo: Dar el-Qalam, t.th

Nina Mariani Noor dan Ro'fah, Praktik Adopsi Anak dan Peran Pekerja Sosial dalam Proses Adopsi Anak di Daerah Istimewa Yogyakarta, Jurnal PKS, vol. 18, no. 2, Agustus. (2019).

Sahal Mahfudz, Solusi Problematika Aktual Hukum Islam, Keputusan Muktamar, Munas, dan Konbes Nahdlatul Ulama 1926-1999 M

Sudarsono, Kamus Hukum, (Jakarta: PT Rineka Cipta dan PT Bima Andiaksara).2005.

Tim Kementerian Perwakafan dan Keislaman, al-Mausucah al-Fiqhiyyah al-Kuwaitiyyah, Kuwait: Dârr al-Salasil, cet. II, Jil. 41. 1427 H.

Wawancara: 
Fathonah K. Daud, H.M. Ridlwan Hambali

Mr, Wawancara Pribadi, Pada hari Sabtu, 8 Januari 2021.

Mah, Wawancara Pribadi, Pada hari Senin, 4 Januari 2021.

M, Wawancara Pribadi, pada hari minggu, 10 januari 2021.

Kh, Wawancara Pribadi, Pada hari Sabtu, 9 Januari 2021.

Kr, Wawancara Pribadi, Pada hari Senin, 11 Januari 2021. 